\title{
DISCURSIVE REPRESENTATIONS OF THE AGRICULTURAL REFORM POLICY IN BRAZILIAN SAVANNA: THE CASE OF DIRECTED SETTLEMENT PROGRAM OF ALTO PARANAÍBA (PADAP)
}

\author{
Representações Discursivas da Política de Reforma Agrária no Cerrado Brasileiro: O Caso do \\ Programa de Assentamento Dirigido do Alto Paranaíba (PADAP)
}

\begin{abstract}
The debate around the Brazilian agrarian issue was historically marked by the presence of different actors and discourses that, for the majority, assumed opposing positions and practices. Specifically, the agrarian reform policy of the 1960s, one of the main historical milestones of this issue, was also developed in the midst of this discursive plurality, which then became two specific discursive orders: the pro-reform discourse and the agricultural modernization discourse. From this conflict resulted different agrarian policies inserted in a socio-historical and political context, highlighting those directed to the rural exploration of savanna. In this sense, the present study aimed to understand the discursive representations and reveal ideological elements present in textual discourses and uttered by governmental implementers of the expansion policies of the agricultural frontier for the Brazilian savanna and beneficiaries of the Directed Settlement Program of Alto Paranaíba (PADAP). Through the analysis of the representational meaning from Norman Fairclough's discourse theory, it was possible to identify the representations involved in the formulation and implementation of this policy, highlighting the hegemony of agricultural modernization inculcated in statements that justified a priori agrarian reform.
\end{abstract}

André Luiz de Paiva

Universidade Federal de Lavras

andrepaiva2@gmail.com

Marilene de Souza Campos

Universidade Federal de Viçosa

marilencrp@gmail.com

Patrícia Aparecida Ferreira

Universidade Federal de Lavras

paf@dae.ufla.br

Luis Fernando Silva Andrade

Universidade Federal de Lavras

andradelfs@gmail.com

Recebido em:20/09/2016. Aprovado em: 21/09/2017.

Avaliado pelo sistema double blind review

Avaliador científico: Rafael Eduardo Chiodi

DOI: 10.21714/2238-68902017v19n3p177

\section{RESUMO}

O debate em torno da questão agrária brasileira foi historicamente marcado pela presença de diferentes atores e discursos que, em sua maioria, assumiam posições e práticas antagônicas. De forma específica, a política de reforma agrária da década de 1960, um dos principais marcos históricos dessa questão, também se desenvolveu em meio a essa pluralidade discursiva, que nesse caso, tomou a forma de duas ordens discursivas em específico: o discurso pró-reforma e o discurso da modernização agrícola. Desse conflito, inserido em um contexto sócio-histórico e político, resultaram diferentes políticas agrárias, ressaltando aquelas voltadas à exploração rural do cerrado. Nesse sentido, o presente trabalho teve como objetivo compreender as representações discursivas e desvelar elementos ideológicos presentes em discursos textuais e proferidos por implementadores governamentais das políticas de expansão da fronteira agrícola para o cerrado brasileiro e beneficiários do Programa de Assentamento Dirigido do Alto Paranaíba (PADAP). Por meio da análise do significado representacional a partir da teoria do discurso de Norman Fairclough foi possível identificar as representações envolvidas nos processos de formulação e implementação desta política, evidenciando a hegemonia da modernização agrícola inculcada em enunciados que, a priori, justificavam a reforma agrária.

Palavras-chave: Reforma Agrária, Modernização Conservadora, Cerrado, Significado representacional, PADAP.

Keywords: Agrarian Reform, Conservative Modernization, Savanna, Representational Meaning, PADAP. 


\section{INTRODUCTION}

The agrarian issue has been a recurring topic in the relationships between the State, the market and civil society, especially considering the process of building agrarian reform policies in the last 70 years, especially in Latin American countries (GRAZIANO DA SILVA, 1982; PAULINO, 2014; ROBLES; VELTMEYER, 2015, ELGERT, 2015; ROSSET, 2013; VILPOUX, 2014).

Specifically, the discussions directed to a public policy of agrarian reform in Brazil became more prominent and entered the political agenda of the State in the 1950s and 1960s, during the government of President João Goulart (1961-1964), which advocated core reforms of the country, including the reform of the land structure, marked by often unproductive large estates. Even though, according to Graziano da Silva (1982), there were different discourses and ideological positions in this period regarding the ways in which reform should be carried out, the Brazilian agrarian issue was mainly seen as a barrier to the economic and social development of the country, being large estate as the main cause of the social and economic problems of the countryside (VERGARA-CAMUS, 2012; DELGADO, 2001).

In this period, on the one hand, social movements constituted by rural workers, left-aligned thinkers on the political spectrum and politicians, such as President João Goulart, (re)produced a discourse in which they defended the realization of agrarian reform through large estate expropriation and redistribution of land in small lots. On the other hand, there was the discourse of economists, agronomists, and conservative thinkers, who also entered the agrarian debate, although they understood that the reform through the large estate expropriation was not the way necessary for economic development, proposing policies aimed at investing and financing the existing land structure, adopting a discursive position focused on capitalist production and agricultural modernization, also influenced by the discourse of the so-called 'Green Revolution' (SANTOS, 2013; SILVA, 2015).

Considering that the agrarian reform was part of the President Goulart's government plan, the Brazil's landowner and industrial elite tried to mobilize themselves in order to exercise a force contrary to this movement. These interests were crucial for the accomplishment of a coup d'état in 1964, instituting a military government in the country. However, as soon as the military assumed the governance, the agrarian issue was not forgotten and that Law no. 4,504/64, also known as the 'Land Statute', was drawn up and enacted in the first year of the regime in order to accomplish the agrarian reform in the country (ROBLES; VELTMEYER, 2015).

According to Carvalho (2011), the 'Land Statute' considered both an agrarian policy, aimed at transforming the country's land structure, marked by unproductive large estate that should be expropriated, as well as an agricultural policy, which is concerned with establishing incentive programs and the development of the rural economy, which would support the integration of agriculture and livestock with industry. It is worth noting, however, that this text did not ignore the demands from other discourses related to the agrarian issue, such as social movements of rural workers, which helped to characterize the conceptual chaos involving the Statute (SILVA, 2015).

Based on the "Land Statute", the first expansion programs of the agricultural frontier were developed for the Brazilian savanna, a biome until then little explored by the agricultural activity of great extension (PIRES, 2000). According to Santos et al. (2014), these savanna colonization policies used a combination of agrarian reform discourses and agricultural modernization that transformed some regions of the biome into national agribusiness poles, as seems to be the case of the Directed Settlement Program of Alto Paranaíba (PADAP), the inaugural policy of this biome's farm (SASAKI, 2008).

Thus, in the face of the "conceptual chaos" that involved the agrarian issue during the 1960s and 1970s and the discursive conflict of the period, we aimed in this study to understand the discursive representations and to reveal ideological elements present in the constitutive political expansion discourses of the agricultural frontier to the Brazilian savanna, especially regarding the PADAP.

In this respect, we will take the perspective of critical discourse analysis (CDA) (FAIRCLOUGH, 2001, 2003; RESENDE, RAMALHO, 2006) as a theoretical and methodological support, recognizing the contributions of this approach to the study of agrarian reform processes (MacDONALD, 2003; KOLAWOLE, 2012; SOUZA; SILVA, 2013; MORAIS, 2014; CABRAL et al. 2016) and highlighting the representational meaning of discourses that constitute the discursive corpus of the formulation processes and implementation of this program.

It is also relevant to bring the conceptual aspects and nomenclature used to deal with those who labor on land or take sustenance from it. The legislation itself is imprecise in this respect and has disregarded traditional agricultural production, such as the peasantry and family farming since the Land Statute (BRASIL, 1964). The generic term 'producer' is

Organizações Rurais \& Agroindustriais, Lavras, v. 19, n. 3, p. 177-191, 2017 
used, which causes the erasure of cultural, historical and social singularities of peasants directly or indirectly affected by State action. One specificity found is the term 'settler', widely used to treat those benefited by agricultural modernization programs, such as farmers from other regions, and specifically regarding the PADAP, its vast majority are Japanese descent. In this article, we use the terms producer (rural), small rural producer and settler, aware of the intentional absence of the peasantry in the analysis corpus.

Thus, besides this introduction (1), this study will be divided into sessions that will comprise a discussion on the agrarian issues and the agrarian policies in the savanna (2); methodological procedures and categories of representational meaning in CDA (3); the PADAP contextualization and the analysis of the discursive corpus in question (4); finally, the final considerations of the study (5).

\section{THEORETICAL FRAMEWORK}

\subsection{The Agrarian Issue in Brazil: Discourses, Ideologies and the Land Statute}

Broadly speaking, the so-called Brazilian agrarian issue can be divided into three moments of discussion: the term's emergence between 1930-1945 (motivated by the international transformations of capitalism); the debate on the agrarian issue as a guide to the Brazil's economic development between 1945 and 1965; and the period of authoritarian or conservative modernization between 1966 and 1990, marked by the implementation of technical and scientific capital and the modernization of the countryside (DELGADO, 2001, ROBLES; VELTMEYER, 2015).

According to Rodrigues (2015, p. 21), the agrarian issue is directly related to the "high concentration of land appropriation, which places the rural population in a subservience situation, promotes degrading work conditions and generates effects and social ills in urban centers".

In this direction, despite the existence of different political movements and interests, it is possible to affirm that two broad-ranging discourses were highlighted during the 1950s and 1960s, marked by distinct characteristics regarding the Brazilian rural environment. The first was related to the prioritization of agrarian reform, seeking to achieve its social purpose, reducing inequalities in land ownership in the rural production means. On the other hand, the second discourse was based on the defense of the industrialization and modernization of agriculture, based on a developmental proposal aimed at assisting growing urban areas and the external market (DELGADO, 2001).
In relation to the first discursive order, however, Graziano da Silva (1982) argues that there were different narratives about agrarian reform in the country, highlighting four of them: the moderate proposal of the Communist Party of Brazil (PCB), which sought to attract bourgeoisie sectors for the reform and set a ceiling of 500 hectares per lot; the radical proposals of the Peasant Leagues, which sought land redistribution, even resorting to armed disputes among those involved; the moderate narrative of the Catholic Church, committed to the expropriation of large unused estates and the sale of them to peasants in expropriated areas; as well as narratives of more radical sectors of the Catholic Church itself that believed in the agrarian reform through the association of peasants to unions that would develop a class consciousness.

However, Soares and Castro (1986, p. 43) broadly understand the concept of agrarian reform as:

[...] the revision and readjustment of the juridical-social and economic-financial norms that govern the land structure of the country, aiming at the valorization of the farmworker and the production increase through the social, rational distribution and utilization of the agricultural property, the better organization and extension of rural credit, and the improvement of rural man's living conditions.

Later, despite several theoretical influences from previous periods, the groups that were positioned in the discourse for agrarian reform began to organize from the 1950s and 1960s, so that their demands took on greater scope and entered the political agenda during the government of João Goulart (1961-1964), which had nationalism and economic development as its guidelines, which would be achieved through grassroots reforms, including agrarian reform. In this period, it should be noted that the country's land structure, composed of large unproductive estates, was seen as a barrier to industrialization and economic development, as well as corresponded to the cause of most of the rural social problems, such as hunger, poverty, illiteracy, among others. In this sense, the agrarian reform proposal presented in João Goulart's Three-Year Plan (1963-1965) consisted of a large estate expropriation process (CARVALHO, 2011).

For Jango, agrarian reform would be the main means for Brazilian economic development, since it was based on the premise that the farmworker who owned his land would have a higher income and would thus help with the industry's investment in the country. In this direction, the government of Goulart elaborated a decree 
establishing norms for the agrarian reform, creating in 1963 the Superintendence of Agrarian Policy (SUPRA), which would promote the execution of expropriation plans and projects of areas characterized as unproductive or uneconomically exploited rural lands; as well as the establishment of rural workers in these areas and investments in productive capital and technical assistance (SANTOS, 2013). According to Carvalho (2011), another important event in this context was the creation of the National Confederation of Rural Workers (CONTAG) in 1963, a trade union body that advocated agrarian reform and other rights for farmworkers. Also in 1963, the federal government created the Statute of the Rural Worker.

On the other hand, from the point of view of groups aligned with the agricultural modernization discourse, such as some economists from the University of São Paulo, statistical and economic information were the basis for claiming the non-existence of the 'agrarian issue' in Brazil, since the land structure until then was not considered as a relevant economic and social problem and should only be modernized and exploited more efficiently. Moreover, Brazil in that period was positioned as a food country importer, so that investment in high-scale production was also a demand for these groups (DELGADO, 2001).

Thus, this chain of actors was aligned with the agricultural modernization discourse, understood by Martine (1991) as the generic process of increasing agriculture integration in the industrial capitalist system, especially through technological innovation and rupture with traditional production relationships characteristics from peasants, based on subsistence agriculture. According to Silva (2015), due to the social, historical and cultural context in which these subjects were inserted, they were considered as unfit for the incorporation and use of new technologies of high specialization.

This narrative was influenced by the American functionalist discourse on the agriculture role in the economy, which would have five economic functions: "Supply labor for industry; generate adequate food supply; supply raw materials for industries; increase agricultural exports [and]; transfer real income to the urban sector" (DELGADO, 2001, p. 161).

Another relevant actor in the construction and legitimation of this discourse was the Institute for Research and Social Studies (IPES), a conservative orientation research agency whose main activities were developed in the 1960s, mainly seeking to disrupt the political project of João Goulart. IPES carried out studies proposing a land reform project aimed at the formation of a rural middle class, based on owners (small, medium or large) who already had capital and knowledge for modern and mechanized rural production, progressively eliminating unproductive large estates, even though the large estate structure was not criticized and the equalized land distribution was not defended.

In other words, agrarian reform for the IPES could not be based solely on land distribution (expropriation and land distribution to individuals and groups), so that this process should be aligned with the notion of agriculture modernization and the end of unproductive large estate and smallholding. This policy was based on the idea ofthe land tax instead of the land confiscation by the State. Thus, the government would act progressively, implanting the family rural middle class in unproductive lands and financing the activity of these groups (SILVA, 2015).

Furthermore, according to Carvalho (2011), the agricultural modernization discourse in Brazil was strongly influenced by the development of the strategy package called Green Revolution (created in the United States by the Rockefeller Institute). This policy established changes in the technical basis of food production around the world, providing technologies for the development of breed seeds, mechanization, and chemical inputs.

Amidst this situation, it was precisely the groups aligned to this perspective of the agricultural issue, allied with part of Brazilian business community, who organized politically and articulated the coup d'état of 1964, deposing President João Goulart and establishing a military dictatorship regime (GRAZIANO DA SILVA, 1982). This new government, however, did not suppress the debate related to agrarian demands. On the contrary, one of its first great actions was the promulgation of Law 4,505/64, also named "Land Statute".

According to Silva (2015), the Land Statute was influenced mainly by groups as the rural and industrial elite, who supported a conservative agrarian policy aimed at modernizing the existing land structure. However, the text presented a series of provisions that provoked contradictions and conflicts. On the one hand, agrarian reform was understood as an outlet for industrialization and economic development, although the rural elite considered this process a violation of property rights. On the other hand, the Statute also appropriated some aspects from proreform discourse, presupposing the land use by attending to its social function and establishing guidelines for the development of agrarian reform based on instruments as expropriation and colonization, as well as defined the payment of expropriated land through government bonds. 
In this sense, the Land Statute establishes in its article $2, \S 1$,

Rural land ownership fully fulfills its social function when, simultaneously:

a) favors the well-being of owners and workers who work there, as well as of their families;

b) maintains satisfactory productivity levels;

c) ensures the conservation of natural resources;

d) observes the legal provisions that regulate the fair labor relationships between those who own and cultivate it (LAW 4,504/1964 ART. 2, § 1 - LAND STATUTE).

However, Souza and Silva (2013), based on article 2, show that the Land Statute did not intend to end the large estate nor to promote a change in the Brazil's land structure, being possible to argue that although the military regime was not opposed to reforms, it did not accept that certain groups, such as peasant organizations and leftist political parties (especially the PCB) to assume the leadership for implementation and operationalization of these reforms. Additionally, the agrarian policy has assumed an economic and technical sense to the detriment of social and political aspects. As evidence of this, the agrarian reform process of the Castelo Branco government was elaborated in a top-down perspective, without the consultation of rural workers, depoliticizing the agrarian issue (SILVA, 2015).

Complementarily, some authors as Salis (2014) and Vergara-Camus (2012) understand that the agrarian reform elaborated in the military government was little about pressures of social movements (mainly because they were forbidden and persecuted): the real motivation of the agrarian reform in the period was the visualization of agrarian structure prevailing until then in the country as a hindrance to economic and industrial development, so that it would be necessary to implement measures that restructured this configuration, aimed at the modernization and technical exploration of areas constituted by large unproductive estates, mainly to meet food demands.

Thus, for Silva (2015), the Land Statute failed to promote agrarian reform because it was enveloped in a kind of conceptual chaos, which led to the development of an agrarian policy aimed at agricultural modernization that was justified simultaneously as an agrarian policy. The products of this context marked the period known as the modernization agricultural policy.

In this direction, according to Martine (1991), Brazilian agricultural modernization can be divided into three phases: conservative modernization (from 1965 to 1979), crisis and retraction (from 1980 to 1984), and recovery and super crops (1985 to 1989). We emphasize that, considering the scope of this study, we will deal especially with the first phase, named initially by the American sociologist Barrington Moore Jr. (ROBLES; VELTMEYER, 2015) due to the modernization proposal that did not directly concern with changing the agrarian structure of the country, maintaining the same pattern and social problems that constituted the Brazilian rural space for centuries.

During the period of conservative modernization, it was up to the state to "increase the production and productivity of the agricultural sector, driven by urban and external demand in a rapid growth process" (DELGADO, 2001 p. 163). Moreover, the agriculture functions would also change, so that the sector should also deepen its technical relationships with industry in order to reach the external market, a process called 'technical-agriculture-industry integration' by Delgado (2001), characterized by the strong presence of industrial products in agricultural activity (pesticides, machinery, etc.) and the industrialization of rural commodities.

Thereby, based on this context, the public expansion policies of the agricultural frontier were developed for the savanna from the 1970s onwards. Although this policy includes different aspects, in the next session we tried to describe in detail the main programs that were said to be related to the land structure implemented in the biome during that period.

\subsection{Agrarian Policies in the Savanna}

State action for the savanna exploitation refers to the Vargas government, starting with the creation of agricultural colonies in the states of Mato Grosso and Goiás, highlighting the colonies of Dourados (MS) and Ceres (GO). After the creation of Brasilia in the 1950s, new incentives to the settlement and rural exploration of the savanna were fostered. However, these actions were essentially based on extensive livestock farming mainly due to lack of nutrients from the biome soil, which prevented the planting and cultivation of crops, a scenario that lasted until the end of the 1960s (SANTOS et al. 2014).

However, based on the discussions involving agrarian reform and agricultural modernization, materialized in the Land Statute and in other instruments and governmental programs, the savanna returned to enter the agenda of the State as a productive space and a means to promote the economic and industrial development of the country (PIRES, 2000).

In this sense, the PADAP is the first agrarian policy of the conservative modernization period focused on the savanna occupation, formulated in partnership between the 
Minas Gerais state government and the federal government in the beginning of the 1970s. However, PADAP will be better analyzed in subsequent sessions, since the discursive representations around this policy constitute the main analysis corpus of this study. Thus, we will discuss other agrarian programs developed in the savanna during this period, most of which are direct results of this inaugural policy.

These policies include the Special Development Program of Grande Dourados, the Special Program of the Geoeconomic Region of Brasilia, the Integrated Program for the Development of Northwest Brazil (POLONOROESTE), the Program for the Savanna Development (POLOCENTRO) and the Japanese-Brazilian Cooperation Program for the Savanna Development (PRODECER). These programs were characterized by the provision of credit and technical assistance by the State to settlers and producers installed in plots of land with productive capacity that met the standards for agricultural modernization (BITTAR, 2011; TANTURE, 2013; SANTOS et al. 2014).

In turn, POLOCENTRO, created in 1975 in the face of the positive evaluation of PADAP, is similar to the last one in relation to research, technical assistance and rural credit, differing in geographical concentration: while PADAP focused on the Alto Paranaíba region, POLOCENTRO was developed in the states of Minas Gerais, Mato Grosso, Mato Grosso do Sul, and Goiás, in 12 poles of growth, with the objective of rationally incorporating three million hectares, spreading new technologies for agricultural production in the savanna, with an investment of 860 million dollars (PIRES, 2000). Despite the amount of invested resources, the program did not reflect an increase in the employed workforce in the occupied regions, also leading to a rise in the land price and a reduction in the number of small rural properties.

POLOCENTRO began to be decommissioned in 1979 , coinciding with the acceleration of negotiations between Brazil and Japan for the implementation of PRODECER, which began in 1975. PRODECER was started in 1980, divided into three consecutive stages performed in several states, as indicated in Chart 1.

\begin{tabular}{ccc}
\hline Name & Year & Site \\
\hline PRODECER I & 1980 & $\begin{array}{c}\text { Coromandel, Iraí de Minas and } \\
\text { Paracatu (MG). }\end{array}$ \\
PRODECER II & 1985 & $\begin{array}{c}\text { Minas Gerais, Goiás, Mato Grosso, } \\
\text { Mato Grosso do Sul and Bahia. }\end{array}$ \\
PRODECER III & 1995 & Pedro Afonso (TO) and Balsas (MA). \\
\hline
\end{tabular}

CHART 1 - Stages of PRODECER

Source: Prepared by the authors based on Silva (2000)
PRODECER differs from previous programs precisely in the collaboration character and presence of Japanese government at different levels, such as "the selection of areas, the granting of credits, the monitoring of productive activities, and the evaluation of performance" (SILVA, 2000, p. 122), whose actions are developed mainly by the Agricultural Promotion Company (CPA)/Campo, formed by Brazilian and Japanese capital.

Another program developed in the savanna during this period was the Special Program of the Grande Dourados Region (PRODEGRAN), in 1976, which aimed to explore the agricultural potential of the state of Mato Grosso, comprising an area of approximately 6 million hectares near the municipality of Dourados.

\section{METHODOLOGICAL PROCEDURES}

Based on the theoretical problematization and foundations presented previously, this study is characterized as a descriptive investigation and of qualitative nature. The discursive analysis corpus comprised essentially texts related to the PADAP formulation and implementation process, systematized from Figure 1. After being collected, the statements were organized (as well as transcribed in the case of interviews) and structured in a text editor software.

As a theoretical and methodological approach to corpus analysis, the critical discourse analysis (CDA) was adopted in the aspect developed by Norman Fairclough (2001, 2003). According to Resende and Ramalho (2006), this perspective allows analyzing social practices through discursive practices or discourses with a performance function in reality. For Fairclough (2001), discourse is understood as both a form of action by which people act and produce effects in the world as well as on other people, and as a form of representation. It is emphasized that several discourses that constitute the domains of social life tend to compete with each other, so that some end up assuming higher positions of power (GRIVINS; TISENKOPFS, 2015; FREITAS et al. 2016; HOWLEY; HOWLEY; EPPLEY, 2013; SOUZA; SILVA, 2013). Therefore, discourses can be shaped and shape social structures.

Furthermore, the CDA has as interest to understand the conditions of production, distribution and consumption of texts, highlighting the context in which they were produced. In this way, it was seek to analyze the purposes of discourses, revealing power relationships among the different actors and considering possible ideological meanings of these statements (FAIRCLOUGH, 2013; MacDONALD, 2003).

Organizações Rurais \& Agroindustriais, Lavras, v. 19, n. 3, p. 177-191, 2017 


\begin{tabular}{|c|c|c|}
\hline $\begin{array}{l}\text { Sources of corpus } \\
\text { collection }\end{array}$ & Description & Dates \\
\hline \multirow[t]{4}{*}{ PADAP expropriation files } & $\begin{array}{l}\text { Set of texts describing legal and administrative procedures related to PADAP. It } \\
\text { involves technical studies, decrees, petitions, requirements, minutes of meetings, } \\
\text { legal decisions, certifications, among others. They are in the Library of the Federal } \\
\text { University of Viçosa - Rio Paranaíba Campus }\end{array}$ & \\
\hline & $\begin{array}{l}\text { Interview with policy maker involved in the formulation and implementation of } \\
\qquad \text { PADAP (Interviewee 1); }\end{array}$ & $8 / 31 / 2011$ \\
\hline & $\begin{array}{l}\text { Interviews with policy maker involved in the formulation and implementation of } \\
\qquad \text { PADAP (Interviewee 2); }\end{array}$ & $\begin{array}{l}9 / 3 / 2011 \\
11 / 14 / 2011 \\
5 / 23 / 2012\end{array}$ \\
\hline & $\begin{array}{l}\text { Interview with researcher, director of one of the policy assistance agencies, Ruralminas, } \\
\text { during the formulation and implementation period of PADAP (Interviewee } 3 \text { ) }\end{array}$ & $8 / 30 / 2009$ \\
\hline \multirow[t]{3}{*}{ Interviews } & $\begin{array}{l}\text { Interviews with settlers of Japanese descent, employee of the Cotia Farming } \\
\text { Cooperative, settled by PADAP (Interviewee 4) }\end{array}$ & $\begin{array}{r}3 / 14 / 2009 \\
6 / 22 / 2009 \\
11 / 13 / 2009\end{array}$ \\
\hline & $\begin{array}{l}\text { Interview with a researcher from the Federal University of Viçosa, active in the } \\
\text { PADAP region (Interviewee 5). }\end{array}$ & $10 / 18 / 2010$ \\
\hline & $\begin{array}{l}\text { Interview with settlers of Japanese descent, employee of the Cotia Farming } \\
\text { Cooperative, settled by PADAP (Interviewee 6) }\end{array}$ & $2 / 18 / 2010$ \\
\hline Legislations & Law 4,504/64 (Land Statute), Decree 72,786/73 & \\
\hline Other sources & $\begin{array}{l}\text { Interview with Alysson Paolinelli, one of the policy makers (held by the Alto } \\
\text { Paranaíba region news portal); Book "Portal of savanna: the stories and adventures } \\
\text { of the pioneers in the clearing and creation of the largest agricultural region in } \\
\text { Brazil", which tells the PADAP formulation and implementation in the perspective of } \\
\text { Japanese descent settlers (SASAKI, 2008). }\end{array}$ & \\
\hline
\end{tabular}

FIGURE 1 - Description of the procedures for corpus collection

Source: Elaborated by the authors

In the Fairclough's CDA context, ideology is understood as a set of socially and historically constructed meanings of reality that reproduce domination relationships among groups of subjects (FAIRCLOUGH, 2001; CHIAPELLO; FAIRCLOUGH, 2002). In this way, some discourses can be understood as ideological practices, since it contributes to the construction of values and norms with greater legitimacy in a broad conjuncture. Specifically regarding this research, senses to certain actors are attributed in a public policy to the detriment of others based on ideological discourses, thus contributing to the reproduction of domination and subordination relationships (MacDONALD, 2003).

Fairclough (2003), based on Haliday, recognizes that discourse has social functions/meanings and proposes that CDA should consider three main types of discourse meanings, namely: actional (the genres by which social practices are propagated); representational (the representation of social reality aspects and its actors through discourses); and identificational (referring to the constructions and negotiations of identities coming from the discourses, characterized by the styles) (RESENDE; RAMALHO, 2006).

According to Fairclough (2003), this meaning classification is only an analytical tool, since these meanings are simultaneously interconnected in social reality. However, considering the purpose of this article, we will deal specifically with the representational meaning of the discourses, involving the formulation and implementation of the PADAP. This type of methodological choice was also employed by Melo (2013), Resende (2008), and Paiva, Garcia and Alcântara (2017).

According to Fairclough, the representational meaning can be analyzed from the following categories: the representation of the social actors, the interdiscursivity, and the semantics of words. The first one refers to "the ways as social actors are represented in texts, which can indicate ideological positions in relation to them and their activities", therefore, "the analysis of such representations can be useful 
in the unveiling of ideologies in texts and interactions" (RESENDE; RAMALHO, 2006, p. 72). Fairclough (2003) rescues the theory of representation of social actors developed by Theo van Leeuwen, from which the representations can be evaluated by (a) inclusion/exclusion; (b) pronominalization; (c) grammatical role; (d) active or passive voice; (e) personalization or impersonalization; (f) nomination or classification; (g) specific or generic. In this research, it was sought to explore how actors involved in PADAP were represented in the analyzed corpus. These actors refer to policy makers (subjects that acted on the political formulation and decision-making), expropriated landowners, peasants working near the expropriated area, settlers from Japanese descent who received land, among others.

In turn, interdiscursivity refers to "the heterogeneity of a text regarding articulation of different discourses", in "[...] harmonious or controversial dialogical relationships" (RESENDE; RAMALHO, 2006, p. 72). Thus, according to Fairclough (2003, p. 128), "the dialogic/polemical relationship is a way in which texts mix different discourses, but their 'own' discourses are often mixed or hybridized". This analysis focuses in the way as texts are articulated through other discourses and statements that permeated the context of policy formation, among which stand out the Land Statute, agricultural modernization, the Green Revolution, pro-agrarian reform movements, among others.

Finally, regarding the semantics of words, Fairclough $(2001 ; 2003)$ states that this is part of disputes within other hegemonic disputes. Therefore, the lexicalization of meanings are collective constructs involving " [...] struggles among conflicting assignments of meanings - and semantic variation is seen as a factor of ideological conflict, since the meanings can be politically and ideologically invested" (RESENDE; RAMALHO, 2006, p. 75). In the analyzed corpus, it was sought to evidence lexical choices that represent and reproduce ideological discourses, especially when dealing with the justifications for the accomplishment of the studied policy.

The analysis from the categories of the representational meaning of discourse allowed understanding certain aspects related to PADAP, especially regarding its reproduction context. In this way, the results of this research are presented in the next section.

\section{RESULTS AND DISCUSSION}

In this session, we seek to develop the analysis of the representational meaning of discourses related to the formulation and implementation stages of the PADAP.
Initially, as part of the analysis, it is necessary to discuss the context in which this policy and related discourses were constructed.

\subsection{Development Context of PADAP}

PADAP is considered the inaugural expansion policy of the agricultural frontier for the savanna. The program formulation process began in 1972 and its subsequent implementation occurred in 1973, specifically comprising the municipalities of São Gotardo, Rio Paranaíba, Ibiá and Campos Altos, located in the Alto Paranaíba region, MG, Brazil. PADAP was characterized by the distribution of land expropriated by the federal government and by a colonization process, in which rural producers selected by the Cotia Farming Cooperative (Brazil's main agricultural cooperative at the time, consisting essentially of Japanese immigrants) granted plots of land where productive activity would be developed through an agricultural credit program integrated with technical and technological assistance offered by state rural research and extension agencies and public universities.

The context in which the program was developed is directly related to the discussions around the model of agrarian and agricultural policy adopted by the military government from the Land Statute. The productive activity performed in the territory that comprised PADAP until the mid-1960s consisted basically of small and mediumsized rural properties organized in a family farming or small-scale farming system, surrounded by a large area characterized as unproductive large estate, owned by an businessman at the time residing in Belo Horizonte, MG, Brazil. It is worth highlighting that, during this period, the Alto Paranaíba region experienced a severe economic crisis and a shortage of resources (SASSAKI, 2008).

Alongside this context, in the early 1970s, a group of technicians from National institute of agrarian development (Instituto Nacional do Desenvolvimento Agrário INDA), an agency that preceded the National institute of colonization and agrarian reform (INCRA), in partnership with the state government of Minas Gerais, through the Minas Gerais development bank, developed a pioneering agricultural credit program called integrated rural credit program (Programa de Crédito Rural Integrado - PCRI), in which the state offered loans and credit to producers in the Triângulo Mineiro region, MG, by presenting a schedule of activities to be developed in the field based on technical information provided by the assistance of INDA technicians. This policy consisted of the first program of its kind in Brazil and was the embryo for PADAP (SANTOS et al. 2014).

Organizações Rurais \& Agroindustriais, Lavras, v. 19, n. 3, p. 177-191, 2017 
Thus, it was from the experience of the PCRI applied in the Triângulo Mineiro region, together with an economic diagnosis and the emergence of a crisis in the food supply throughout the world and that directly impacted Brazil that political leaders, especially from the city of São Gotardo, MG, together with actors from state and federal government agencies, worked together to develop a new program focused on agricultural modernization in the Alto Paranaíba region, however, covering a larger area. This area was initially glimpsed by the recognition of a large estate of approximately 60 thousand hectares, located in the municipalities of Rio Paranaíba, São Gotardo, Campos Altos, and Ibiá. This area, however, comprised not only the large property, whose actual size was approximately 30 thousand hectares, which spread among other small and medium-sized properties.

From the idea of policy formulation, the Cotia Farming Cooperative, the Brazil's main agricultural cooperative at the time was contacted to "assume" the project through political articulation among local leaders and government agencies (SASAKI, 2008). However, in front of the difficulty of negotiations with the owner of the large estate, which, according to Sasaki (2008), also involved ethnic and cultural prejudice against Japaneseborn cooperates, the president of the Cotia Cooperative used his "access" to the federal government, where an expropriation decree was articulated.

Thus, from this articulation, the Decree 72,786 of September 13, 1973 was instituted, thus establishing the area to be expropriated "for social purposes", justifying such action as a land reform policy. The decree initially provided for the expropriation of an area of 61,570 hectares distributed among 53 owners. However, it should be noted that, through protest and resistance actions, owners of properties with less than 100 hectares included in the polygon area demarcated to be expropriated would no longer be under the effect of the decree.

Thus, 25,542.04 ha were allocated to 95 plots of PADAP in the municipalities where the program was implemented, considering the ownership repossession process for small producers affected by the expropriation. The remaining area for the distribution of plots was allocated for small producers, whose activities had already been carried out in the region for many years, in family traditions, which had land expropriated, under the condition that they were explored according to PADAP standards. However, there was little support given to the remnants, and these were even classified as owners of limited aspirations (SASAKI, 2008).
It is important to note that the settlement lots offered to Cotia settlers, farmers of Japanese descent, many of them with agronomic training, had an area between 250 and 500 hectares, a size defined by technical knowledge actors involved in the formulation of the program because they assumed that a lower area would not be feasible for the desired mechanization and productivity levels. This was a sui generis characteristic of PADAP in the face of land expropriation experiences in Brazil, especially considering the size of other settlements developed in the country (especially after the period of conservative modernization), whose average area would be 40 hectares. It is also worth mentioning that the Cotia Cooperative would be interested in expanding its operation area and guaranteeing lands to the children of its cooperative located in the interior of Paraná, since the state no longer offered availability of land to them. It is noteworthy that many settlers of Japanese descent had agronomic training, including experiences in countries as the United States, which influenced the development of the modernization model based on farms ${ }^{1}$, replicated in PADAP.

Besides the Cotia Cooperative's role, the program was developed supported by several companies and public organizations, such as the Agricultural research agency of the state of Minas Gerais (EPAMIG), the Technical Assistance and Rural Extension Company of the State of Minas Gerais (EMATER), Rural Foundation of Minas Gerais (Ruralminas), federal universities (mainly UFLA and UFV), and the Development Bank of Minas Gerais, which offered resources and technologies for research and rural credit aimed at mechanization, improvement of inputs and planting of crops that until then were not developed in the savanna, such as garlic, soy, carrot, maize, among others.

\subsection{Analysis of the Representational Meaning of PADAP Formulation and Implementation Discourses}

Taking as reference the context in which the PADAP was developed, we will discuss the representational meaning of discourses related to the formulation and implementation processes of this policy. To this end, we

${ }^{1}$ Although the discussion on farms and farmerization of agriculture is extensive, it should be pointed out briefly that the model of agricultural production and land use in PADAP is based on the North American model, based on small and medium-sized properties, whose agricultural production is highly mechanized. The context of inequality of access to rural credit and high interest rates for the acquisition of agricultural machinery would then lead to a farmerization process, taking large estates, now divided into smaller, productive plots from an economic point of view, but not considering democratization aspects of land ownership, leading to the unsustainable permanence of the peasantry, replaced by farmers. 
will try to highlight the representation of the social actors involved in the program, as well as the interdiscursivity and the semantic meaning of words used in these discourses.

Thus, considering the analysis corpus used in this study, the presence of capitalist ideologies and agricultural modernization in the appropriation of agrarian reform discourse by policy makers of the military government is evident in the formulation and implementation process of PADAP. This sense is highlighted as common in different agrarian policies developed over the years in diverse contexts worldwide (e.g. ELGERT, 2015; VERGARA-CAMUS, 2012; KOLAWOLE, 2012; SOUZA; SILVA, 2013).

Decree No. 72,786, published in September 1973, which expressed the terms for the expropriation of area to be used in the program, evidences this direction when defining,

Art. 1 It is declared of social interest, for the expropriation purposes, under the terms of articles 18, letter " $d$ " and 20, item VI, of Law No. 4,504 of November 30, 1964, a land area measuring approximately 56,754 hectares (fifty-six thousands, seven hundred and fifty-four) hectares from several owners, located in the municipalities of Paranaíba, Campos Altos and São Gotardo, in the State of Minas Gerais [...] (DECRETO LEI No 72,786/73, emphasis added)

It is important to highlight that the "social interest" through which the expropriation of the area in question was justified based on articles 18, letter "d" and 20, item VI, present in the Land Statute. The letter "d" of article 18 justifies that it is considered a social interest "to allow the social and economic recovery of regions" (emphasizing that the expression "social recovery" refers to broad abstract and generic meaning regarding the 'social' concept, which can also assume an economic aspect), evidencing the centrality of the project's economic dimension, especially when considering item VI, article 20 of the same law, which assigns priority to expropriation to "lands whose current use, studies carried out by the Brazilian Institute of Agrarian Reform prove not to be adequate to its vocation of economic use" (DECRETO LEI No 72,786/73, emphasis added).

It is noted that the article 18 of the Land Statute presents eight justifications (from letters "a" to "h") for expropriation assuming social interest, including "condition the land use to its social function", which refers to other aspects of rural activity, such as the conservation of natural resources, the well-being of owners, workers and families; and "promote the fair and proper distribution of property", evidencing a 'pro-agrarian reform' interdiscourse. Likewise, article 20 presents in its section I that the expropriation of smallholding and large estate is a basic priority. Such discourse makes it possible to highlight the exclusion of interests related to the equated land distribution and to the solution of social problems of the countryside, similarly as it shows how the ideological discourse of agricultural modernization operates through the universalization (THOMPSON, 1995) of economic interests to the detriment of other interests as a means to legitimize politics.

In addition, the interdiscursivity present in Decree $72,786 / 73$ shows that the choice of discourses legitimized by the Land Statute that would justify the expropriation of the area destined to the implementation of PADAP represented essentially the interests of groups aimed at the agriculture modernization, disregarding social aspects resulting from land concentration in the region and the living conditions of smallholders. Moreover, there are no references in the Decree to the terms 'large estate' and 'smallholding', demarcating a non-concern with the modification of these types of land structures in the program and simultaneously classifying all the owners that constitute the polygon to be expropriated as economically unfit and thus barriers to the country's economic development. It should be noted, however, that Article 3 of the same Decree establishes that properties inserted within the expropriation area with an area lower than 100 hectares would be excluded from the effects of the text, although they could benefit from the program structure.

In short, from this text, it is possible to observe the interdiscourse with the important 'conceptual chaos' in the Land Statute (SILVA, 2015), whereas considers and proposes instruments for agrarian reform aiming at a social function of equalization of the land structure, simultaneously allows reproducing the ideological discourse of agricultural modernization for economic purposes.

In the same way, it is possible to observe such discursive confusion and the traits of agricultural modernization ideology when considering the concept of 'settlement' presented by Bergamasco and Norder (1996, p. 8, emphasis added), understood as

[...] the creation of new agricultural production units through government policies aimed at reordering land use for the benefit of landless or little land workers. As its meaning refers to the fixation of the worker in agriculture, it also involves the availability of adequate conditions for land use and the encouragement of social organization and community life. 
Thus, when compared to the representation of the word 'settlement' in the program's name, it is evident the disconnection to this concept and the non-concern of the formulators to benefit actors harmed by the agrarian issue. The definition of the lot area (between 250 and 500 hectares), directed to Cotia cooperates with technical knowledge and production means, characterizes this colonization process in line with the purposes of conservative modernization (DELGADO, 2001). As evidence of this and as observed in the PADAP files, some settlers of the same family received lots of neighboring land, whose production happened without obeying a demarcation of confrontations, configuring the formation of properties with an area larger than 1000 hectares, i.e., new large estates.

Still as an example of the representation of capitalist ideology and agricultural modernization in this program, an attorney general of the state of Minas Gerais argued in a petition addressed to the federal court that,

[..] aiming at the rational use of those lands, provided for art. 20 of the Land Statute, thus providing economic and legal solutions to the matter, in order to reduce the existing gap between industrial and agricultural development, the petitioner, in the Public power body in charge of the promotion and execution of Agrarian Reform, comes by the present to expropriate judicially the cited properties, [...].

In this fragment, the petitioner seeks to justify expropriation for the purposes of a "rational use of the land", i.e., it relies on the discourse of an instrumental rationality, aimed at achieving ends in a utilitarian way, referring in this case to the agriculture modernization process. This type of argument is also often used as a means of justification and legitimation of capitalist ideology (CHIAPELLO; FAIRCHLOUGH, 2002).

It is important to note that these discourses were also situated in a macroeconomic context in which Brazil was an import country, although it was seen internationally as an "agricultural power". Thus, according to the following texts, extracted from interviews with two policy makers (actors who participated in the decision making and implementation of the policy) of PADAP, it can be noted that the agricultural modernization discourse was supported on the discourse of a so-called "global supply crisis" to inculcate its ideological effects in the formulation and implementation processes of the program,

[there was a] world chart showing the following: there are more people willing to buy from Brazil, and Brazil has to prepare to offer (INTERVIEWER 1, emphasis added).
Brazil would crash, that is when we had the need to look for alternatives. Where to produce? Through preliminary studies already existed and through a concentrated effort, we identified a savanna that was a great alternative for Brazil. We have more than 200 million hectares of savanna. We had a small technology, although we had initial confidence and in less than 20 years we have developed a more advanced technology that the world knows for tropical agriculture, which became important to the people inasmuch as farms no longer supply the world's needs [...] (PORTAL SG AGORA - Interview with Alysson Paulinelli, 2015, emphasis added).

Thus, it is possible to perceive with the use of expressions as "There are more people willing to buy from Brazil", "Brazil would crash" and "great alternative for Brazil" the ideological strategy of unification through symbolization (THOMPSON, 1995) of a Brazil's developmentalist project that would necessarily involve the agriculture modernization.

In this sense, as traits of the developmentalist discourse present among technical staff members of the State, one of the interviewees argues that PADAP was not seen as an experience or adventure, but as "the only possible way for national agricultural development" (INTERVIEWER 3). In addition, another fragment representing this discourse is present in,

[PADAP] was the basis for all this development. The farmers were able to accept technologies that we were suggesting, they participated in the innovation process and developed the savanna here as a base for other regions (PORTAL SG AGORA - Interview with Alysson Paolinelli, 2015, emphasis added).

However, another interpretation of the formulation and implementation processes can be presented. One interviewee, when asked about the justifications that led to the savanna's agricultural exploration, stated that the interests were linked to demands other than the need for internal supply following urban sprawl or international trade agreements. In the words of the interviewee,

[The variable] that weighed the most [in the program development] was the demand of children from Japanese immigrants who had already saturated their capacity to produce, mainly in São Paulo and Paraná states, since they were never in general owners of large areas, then there was no longer one generation with agricultural potential, there was more than potential, there was education and interest to keep on the land (INTERVIEWER 1).

Thus, we understand that the savanna exploitation policies were aligned with the combination of potential 
agricultural entrepreneurs, represented by the generation of Japanese rural producers, plus the discourse focused on the need for "development" of the state of Minas Gerais and thus of Brazil itself, who until that time was a food importer. Thus, it was convenient for those involved that the agricultural exploitation policy of the savanna be developed by people with experience and production means for such purposes.

In short, the objective of those involved in PADAP would be to implement an agricultural modernization project based on farmerization, mechanization and the strong presence of scientific capital, especially by the presence of high level researchers from Brazilian universities, such as UFLA and UFV. According to one of the interviewed settlers, Japanese descendant and agricultural engineer:

The idea was that PADAP's agrarian reform was not social like the others, it was only economic. The plantation should use technology in lands of sufficient size to support mechanization. A group from here went to the United States to work on the farms to learn how to do it there. Cotia paid for everything. It was to have a lot of productivity. Doing like the Americans. It was the settler and the machines. We came young, no family, without machine, there was no way to produce, it was never intended to be family farming. It had to be all modern (INTERVIEWED 4).

The justification of the unemployment model of instrumental character adopted is made in the discourse of this settler:

Here, everything was large estate, unproductive land, without any small property, no... I do not know this story about 100 hectares. People here did not enter in reform because they had no interest. If I wanted I could... They threw sugar on the tractors. Then, the army came to protect us. They called the people of sparrow (INTERVIEWER 4).

In this sense, the choice for the official colonization model is justified, mediated by the Cotia Cooperative, an organization marked by its investment strategies and programs in Science and technology of its cooperates. It was not convenient for the actors involved in the formulation of this policy to allocate the state effort in the development of the 'agrarian issue' in the region, structurally changing the rural working conditions in the savanna, starting from the region's own producers and landowners. However, in the policy formulation and implementation process, 'conceptual chaos' (SILVA, 2015) becomes evident in the discourse of policy makers, especially through the use of the Land Statute as an instrument for legitimizing the reproduction of an ideological discourse aimed at agricultural modernization.

\section{FINAL CONSIDERATIONS}

In this study, we seek to understand, through the categories of the representational meaning of discourse offered by the CDA, the discourse representations involving the formulation and implementation processes of the PADAP, especially highlighting the discourses (re) produced by policy makers and settlers who received lands in the policy area and their representations around the Brazilian 'agrarian issue'. We understand that this proposal innovates by revealing empirical representations of a little discussed policy from a reference of public policies and discursive analyses.

We understand that the agrarian reform proposal advocated by agronomic engineers and conservative economists, endorsed by the military government and used as a legal justification for the implementation of PADAP, had as its main characteristic an ideological discourse aimed at promoting agricultural modernization, distancing itself from pro-agrarian reform discourse assumed by social movements of the countryside and political leaders of the left during the 1960s (especially in the government of João Goulart).

However, this study does not question the program results, although several papers show impacts in the Alto Paranaíba region and in the savanna region as a whole, showing the economic growth and the increase in social indicators, even though emphasizing damages and negative impacts to the environment from agricultural modernization with a focus on extensive irrigated planting, use of chemical pesticides, and deforestation of the native vegetation of the biome (SANTOS et al. 2014).

However, it should be highlighted that the agricultural modernization project adopted through a colonization program did not consider the possibility of focusing the policy resources to the population already established in the region, composed of families of producers distributed in small and medium-sized properties, which mostly did not have basic education and did not have production means that would at first attend to the exploration objectives and strategies of the field through mechanization and integrated credit.

On the contrary, these subjects and their social and historical conditions were not considered in the formulation process, which was reflected in existing

Organizações Rurais \& Agroindustriais, Lavras, v. 19, n. 3, p. 177-191, 2017 
conflicts in the implementation and adaptation of them to the credit policy and technical assistance due to their unfamiliarity with own discourses of the financial market and scientific knowledge (SASAKI, 2008). We also note that terms like "peasantry" were silenced in the analyzed discursive representations.

The PADAP formulation and implementation process also highlights the conflict and the conceptual and discursive chaos involved in the Land Statute insofar as the program used agrarian reform instruments, but the main interest in question was not based on the land redistribution seeking to serve social ends and to combat the ills of the countryside.

It is also important to highlight the importance of research and reflect on the discursive practices of a past and already consolidated agricultural and agrarian policy. Even if they reflect the historical and political context of the 1970s, the ideological clash between the social function of the land and its rational use is still present today, not only in the agrarian issue, but also in the urban issue. In this sense, we argue that the CDA can still provide greater impetus for the analysis of public policies and discussions around this theme.

Even if more than 40 years have passed, the actuality of discursive practices and the appropriation of different meanings by capitalist discourse still remains. The analysis of public policies can incorporate the dimension of discourse, which is always performative and affects reality, thus revealing the diverse interests of policy makers and other social actors involved in the whole political process. In other words, the experiences surrounding the PADAP increase the debate about the agricultural and agrarian policies of the Brazilian savanna and serve as reference for the understanding of contemporary conjunctures in this space, as well as for the formulation of new policies.

As limitations, we recognize that the cut used in this study did not conform to all the discourses involved in the policy formulation and implementation processes, nor understood the voices of all actors as an extension of this discursive corpus.

It is suggested to analyze other discourses in future studies, as well as to develop analysis on the actional and identificational meanings involved in the development of PADAP or other agrarian policies that marked the period of conservative modernization in Brazil. In the same way, it is suggested an extension of the study when considering other agrarian reform practices that happened in the Alto Paranaíba region from the 1990s, some of them even involving areas that received incentive due to PADAP.

\section{REFERENCES}

BERGAMASCO, S.; NORDER, L. O que são assentamentos rurais? São Paulo: Brasiliense, 1996.

BITTAR, I. M. B. Modernização do Cerrado brasileiro sustentável: revendo a história. Revista Verde de Agroecologia e Desenvolvimento Sustentável, Mossoró, v. 6 n. 1, p. 26-30, 2011.

BRASIL. Decreto ${ }^{\circ}$ 72.786, de 13 de setembro de 1973. Declara de interesse social, para fins de desapropriação, imóveis rurais situados nos municípios de Rio Paranaíba, Campos Altos e São Gotardo, no Estado de Minas Gerais, compreendidos na área prioritária de emergência, para fins de Reforma Agrária de que trata o Decreto $\mathrm{n}^{\circ} 72.381$, de 19 de junho de 1973. Diário Oficial da União, Brasília, DF, 14 set. 1973. Seção 1, p. 9225.

. Lei $\mathrm{n}^{\circ} 4.504$, de 30 de novembro de 1964. Dispõe sobre o Estatuto da Terra, e dá outras providências. Diário Oficial da União, Brasília, DF, 30 nov. 1964. Seção 1. Disponível em: <http://www.planalto.gov.br/ccivil_03/ leis/L4504.htm>. Acesso em: 10 jan. 2016.

CABRAL, L. et al. Brazil's agricultural politics in Africa: More food international and the disputed meanings of "family farming". World Development, New York, v. 81, p. 47-60, 2016.

CARVALHO, N. D. Luta pela terra no Triângulo Mineiro/Alto Paranaíba: a trajetória dos movimentos e organizações sociais na construção do território. 2011. 140 f. Dissertação (Mestrado em Ciências Humanas)Universidade Federal de Uberlândia, Uberlândia, 2011.

CHIAPELLO, E.; FAIRCLOUGH, N. Understanding the new management ideology: a transdisciplinary contribution from critical discourse analysis and new sociology of capitalism. Discourse Society, London, v. 1, n. 2, p. 185-208, 2002.

DELGADO, G. C. Expansão e modernização do setor agropecuário no pós guerra: um estudo da reflexão agrária. Estudos Avançados, São Paulo, v. 43, n. 15, 2001. Disponível em: $<$ https://goo.gl/iGkx6k>. Acesso em: 10 jan. 2016.

ELGERT, L. 'More soy on fewer farms' in Paraguay: challenging neoliberal agriculture's claims to sustainability. 
The Journal of Peasant Studies, London, v. 43, n. 2, p. 537-561, 2016.

FAIRCLOUGH, N. Analysing discourse: textual analysis for social research. London: Routledge, 2003.

Critical discourse analysis and critical policy studies. Critical Policy Studies, London, v. 7, n. 2, p. 177-197, 2013.

. Discurso e mudança social. Brasília, DF: Ed. UnB, 2001.

FREITAS, R. C. et al. Relações interorganizacionais em grupos de pequenos produtores familiares no sul de Minas Gerais: reflexões críticas e inovações sociais. Organizações Rurais \& Agroindustriais, Lavras, v. 18, n. 1, p. 39-51, 2016.

GRAZIANO DA SILVA, J. A modernização dolorosa: estrutura agrária, fronteira agrícola e trabalhadores rurais no Brasil. Rio de Janeiro: Zahar, 1982.

GRIVINS, M.; TISENKOPFS, T. A discursive analysis of oppositional interpretations of the agro-food system: a case study of Latvia. Journal of Rural Studies, New York, v. 39, p. 111-121, 2015.

HOWLEY, M.; HOWLEY, A.; EPPLEY, K. How agricultural science trumps rural community in the discourse of selected US history textbooks. Theory $\&$ Research in Social Education, London, v. 41, n. 2, p. 187-218, 2013.

KOLAWOLE, O. D. Agrarian reforms and the African green revolution. World Journal of Science, Technology and Sustainable Development, Bingley, v. 9, n. 4, p. 301-316, 2012.

MACDONALD, C. The value of discourse analysis as a methodological tool for understanding a land reform program. Policy Sciences, Berlin, v. 36, n. 2, p. 151-173, 2003.

MARTINE, G. A trajetória da modernização agrícola: a quem beneficia? Revista Lua Nova, São Paulo, n. 23, mar. 1991. Disponível em: <http://www.scielo.br/scielo. php?script=sci_arttext\&pid=S0102-64451991000100003>. Acesso em: 10 jan. 2016.
MELO, I. F. de. Ativismo LGBT na imprensa brasileira: análise crítica da representação de atores sociais na Folha de S. Paulo. 2013. 384 p. Tese (Doutorado em Filologia e Língua Portuguesa)-Universidade de São Paulo, São Paulo, 2013.

MORAIS, H. A. Território e a dimensão espacial do discurso em torno dos assentamentos rurais. Revista Movimentos Sociais e Dinâmicas Espaciais, Recife, v. 3, n. 2, p. 298-318, 2014.

PAIVA, A. L.; GARCIA, A. S.; ALCÂNTARA, V. C. Disputas discursivas sobre corrupção no Brasil: uma análise discursivo-crítica no Twitter. Revista de Administração Contemporânea, Rio de Janeiro, maio 2017. Disponível em: <http://www.anpad.org.br/periodicos/arq_pdf/ ahead_74.pdf $>$. Acesso em: 10 jul. 2017.

PAULINO, E. T. The agricultural, environmental and socio-political repercussions of Brazil's land governance system. Land Use Policy, Guildford, v. 36, p. 134-144, 2014.

PIRES, M. O. Programas agrícolas na ocupação do cerrado. Sociedade e Cultura, Uberlândia, v. 3, n. 1/2, p. 111-131, jan./dez. 2000.

PORTAL SG AGORA. Exclusivo: portal SG AGORA entrevista ex-Ministro da Agricultura Dr. Alysson Paolinelli. 21 out. 2015. Disponível em: <http://www. sgagora.com.br/sg/exclusivo-portal-sg-agora-entrevistaex-ministro-da-agricultura-dr-allyson-paolinelli/>. Acesso em: 10 jan. 2016.

RESENDE, V. M. Análise de discurso crítica e etnografia: o movimento nacional de meninos e meninas de rua, sua crise e o protagonismo juvenil. 2008. 332 p. Tese (Doutorado em Linguística)-Universidade de Brasília, Brasília, DF, 2008.

RESENDE, V. M.; RAMALHO, V. Análise crítica do discurso. São Paulo: Contexto, 2006.

ROBLES, W.; VELTMEYER, H. The politics of agrarian reform in Brazil: a historical background. In: . The politics of agrarian reform in Brazil: the Landless Rural Workers Movement. New York: Palgrave MacMillan, 2015. p. 65-84.

Organizações Rurais \& Agroindustriais, Lavras, v. 19, n. 3, p. 177-191, 2017 
RODRIGUES, F. C. A questão agrária no Brasil: as contribuições de Caio Prado Júnior, Florestan Fernandes e Octávio Ianni. In: NOVAES, H.; MAZIN, A. D.; SANTOS, L. (Ed.). Questão agrária, cooperação e agroecologia. São Paulo: Outras Expressões, 2015. p. 21-39.

ROSSET, P. Re-thinking agrarian reform, land and territory in La Via Campesina. Journal of Peasant Studies, London, v. 40, n. 4, p. 721-775, 2013.

SALIS, C. L. G. Estatuto da Terra: debates políticos e as disputas pela forma da reforma agrária no primeiro governo militar. Antíteses, Londrina, v. 7, n. 13, p. 493-516, 2014.

SANTOS, J. C. Um breve ensaio sobre a questão agrária no Brasil: da colonização a modernização da agricultura: uma contribuição para o entendimento do sistema agroindustrial do leite. Formação, Brasília, DF, v. 1, n. 10, 2012. Disponível em: <https://goo.gl/sPBePr>. Acesso em: 10 jan. 2016.

SANTOS, M. A. et al. Programa de assentamento dirigido do alto paranaíba: o marco inicial do processo de ocupação do cerrado brasileiro. Revista Brasileira de Educação e Cultura, São Gotardo, n. 8, 2014. Disponível em: $<$ https:// goo.gl/LEU6jW>. Acesso em: 10 jan. 2016.

SASAKI, L. I. Portal do cerrado: as histórias e aventuras dos pioneiros no desbravamento e na criação da maior região agrícola do Brasil. Belo Horizonte: O Lutador, 2008.
SILVA, J. M. M. O Estatuto da Terra: a construção da reforma agrária limitada do primeiro governo da ditadura civil-militar. 2015. 173 f. Dissertação (Mestrado em Sociologia)-Universidade de Brasília, Brasília, DF, 2015.

SOARES, H. P.; CASTRO, M. E. A questão da reforma agrária. Revista de Administração Pública, Rio de Janeiro, v. 20, n. 3, p. 40-53, 1986.

SOUZA, C. A. L.; SILVA, D. E. G. Discurso e reforma agrária em alguns textos institucionais do Brasil. Cadernos de Linguagem e Sociedade, Brasília, DF, v. 14, p. 192211, 2013.

TANURE, T. O processo de ocupação recente do cerrado. CEPPG Revista, Catalão, v. 29, p. 107-117, 2013.

THOMPSON, J. B. Ideologia e cultura moderna. Petrópolis: Vozes, 1995.

VERGARA-CAMUS, L. The legacy of social conflicts over property rights in rural Brazil and Mexico: current land struggles in historical perspective. The Journal of Peasant Studies, London, v. 39, n. 5, p. 1133-1158, 2012.

VILPOUX, O. F. Agrarian reform and cooperation between settlers in the Midwest of Brazil: an institutional approach. Land Use Policy, Guildford, v. 39, p. 65-77, 2014. 